\title{
A Genuine Ground in Summary Judgment for Rule 11
}

\author{
Beverly Dyer
}

The Federal Rules of Civil Procedure provide courts with two means for evaluating the validity and truthfulness of factual allegations before trial: the Rule 56 requirement that claims present a "genuine" factual issue $^{1}$ and the Rule 11 requirement that papers submitted to the court be "grounded" in fact. ${ }^{2}$ Likewise, the Rule 11 requirement that papers be "warranted" by law ${ }^{3}$ and the Rule 12(b)(6) requirement that a pleading "state a claim" both authorize pre-trial evaluation of legal claims. (Rule 12(b)(6) motions are controlled by Rule 56 when documents other than the pleadings are considered.) ${ }^{5}$ Rule 56 , aimed at clearing the courts of cases that present solely legal issues, authorizes dismissal of claims under summary judgment. Rule 11, aimed at curbing frivolous litigation, authorizes sanctions against an attorney or party. These Rules provide different remedies and certain different requirements ${ }^{\boldsymbol{b}}$ but they overlap in purpose; Rule 56, like Rule 11, has been described as aimed at reducing frivolous litigation. ${ }^{7}$ They also overlap in application to evaluate factual and legal

1. FED. R. CIv. P. 56(c) authorizes summary judgment. The relevant part of the Rule states that "the judgment sought shall be rendered forthwith if the pleadings, depositions, answers to interrogatories, and admissions on file, together with the affidavits, if any, show that there is no genuine issue as to any material fact and that the moving party is entitled to judgment as a matter of law." A summary judgment motion may be made at any point in the pre-trial proceedings after the pleadings have been submitted.

2. FED. R. Crv. P. 11 authorizes sanctions for frivolous claims. The relevant part of the Rule states: "The signature of an attorney or party constitutes a certificate by the signer that the signer has read the pleading, motion, or other paper; that to the best of the signer's knowledge, information, and belief formed after reasonable inquiry it is well grounded in fact and is warranted by existing law or a good faith argument for the extension, modification, or reversal of existing law, and that it is not interposed for any improper purpose, such as to harass or to cause unnecessary delay or needless increase in the cost of litigation." A Rule 11 motion may be made at any time before, during, or after trial.

3. More accurately, Rule 11 provides that a paper must be "warranted by existing law or a good faith argument for the extension, modification, or reversal of existing law." Id.

4. FED. R. Civ. P. 12(b)(6) provides for dismissal of a pleading for "failure to state a claim upon which relief can be granted."

5. FED. R. Crv. P. 12(b) states: "If, on a motion asserting the defense numbered (6) to dismiss for failure of the pleading to state a claim upon which relief can be granted, matters outside the pleading are presented to and not excluded by the court, the motion shall be treated as one for summary judgment and disposed of as provided in Rule 56 ..."

6. Rule 56 requirements for a "disputed" factual issue and "material" facts bear no relationship to Rule 11, and Rule 11's requirements that papers be filed only after reasonable inquiry and with no improper purpose bear no relationship to Rule 56 .

7. See, e.g., Zaldivar v. City of Los Angeles, 780 F.2d 823, 830 (9th Cir. 1986) (Rule 11 directed 
claims and yet they authorize different standards for similar evaluations. This Note argues for use of the same standard where Rule 11 overlaps with Rules 56 and $12(\mathrm{~b})(6) .^{8}$

Findings of fact are usually made by judges or juries at trial where they are governed by rules of evidence and trial procedures; pre-trial findings of fact can raise Seventh Amendment concerns. ${ }^{9}$ Concerns about potentially unfair pre-trial dismissal of claims have led courts to adopt cautious standards for both Rule 56 and Rule $12(\mathrm{~b})(6) \cdot{ }^{10}$ Over time, the Rule 56 standard for a "genuine" factual issue has become widely accepted. ${ }^{\text {" If a }}$ question of genuineness arises, courts deny summary judgment unless it is clear that the relevant allegations cannot be proven at trial. ${ }^{12}$ This is only

at frivolous claims); Blackhawk Heating \& Plumbing v. Driver, 433 F.2d 1137, 1141 (D. C. Cir. 1970) (Rule 56 serves "admirably to eliminate . . . frivolous lawsuits"); FED. R. CIv. P. 11 advisory committee's note to 1983 amendments (aim of Rule 11 to "streamline the litigation process by lessening frivolous claims or defenses"); 10 C. Wright, A. Milleer, \& M. Kane, Federal. Practice AND Procedure $\$ 2712$, at 563, 579 (2d ed. 1983) (summary judgment "well adapted to expose sham claims and defenses"); Clark, The Summary Judgment, 36 MINN. L. REv. 567, 568 (1952) (summary judgment appropriate for sham or frivolous defenses); Comment, The Effect of Presumptions on Motions for Summary Judgment in Federal Court 31 UCLA L. REv. 1101, 1129 (1984) (purpose of Rule 56 to ameliorate the threat of harrassing and coercive litigation).

8. Judge Schwarzer, one of the most prominent commentators on both Rule 11 and Rule 56, does not agree that the Rules overlap: "Compliance with Rule 11, intended to prevent abuse of the litigation process, raises different issues from those arising under Rule 56, intended to avoid unnecessary trials." Schwarzer, Summary Judgment: A Proposed Revision of Rule 56, 110 F.R.D. 213, 220 (1986). Schwarzer has written extensively about both rules, see infra notes $11,19,21$, and 82 , and is the most widely cited authority on Rule 11 . Note, Has a 'Kafkaesque Dream' Come True? Federal Rule of Civil Procedure 11: Time For Another Amendment?, 67 B.U.L. REv. 1019, 1036 n.112 (1987). Even Schwarzer, though, has alluded to the relationship proposed by this Note. See infra note 19.

9. See Note, Summary Judgment and Circumstantial Evidence, 40 STAN. L. Rev. 491, 492 (1988) (pre-trial factual findings could potentially infringe on party's Seventh Amendment right to jury trial); 10 C. WRIGHT, A. Miller, \& M. KANE, supra note 7, $\$ 2714$ (discussing concerns about right to jury trial in summary judgment); see also Risinger, Honesty in Pleading and Its Enforcement: Some "Striking" Problems with Federal Rule of Civil Procedure 11, 61 MinN. L. REv. 1, 16 (1976) (Rule 11 determination of dishonesty independent of falsity would be of "dubious constitutionality" under Seventh Amendment).

10. See 10 C. Wright, A. Miller, \& M. KANe, supra note 7, § 2712, at 587 (summary judgment used cautiously); 2A J. MoOre, J. Lucas, \& Groetheer, Jr., Moore's Federal. Practice If 12.07 (2d ed. 1989) (Rule 12(b)(6) used cautiously).

11. It is well established that a factual allegation is genuine under summary judgment if reasonable persons could disagree about its truth. See Asbill and Snell, Summary Judgment Under the Federal Rules-When an Issue of Fact is Presented, 51 Mich. L. Rev. 1143, 1171 (1953); Schwarzer, Summary Judgment Under the Federal Rules: Defining Genuine Issues of Material Fact, 99 F.R.D. 465,481 (1984). Rule 56, though, has not eluded all controversy. See, e.g., Sonenshein, State of Mind and Credibility in the Summary Judgment Context: A Better Approach, 78 Nw. U.L. REv. 774, 776-77 (1983) (discussing "uncertainty of the courts" and "apparent confusion" surrounding application of Rule 56); Comment, Summary Judgment: The Majority View Undergoes a Complete Reversal in the 1986 Supreme Court, 37 EMORY L.J. 171-73 (1988) (Rule 56 has been "fertile source of controversy"; current Supreme Court attitude invites more expansive use of Rule but does not raise new arguments). However, most of the controversy surrounding Rule 56 has focused on the burden of proof of moving and non-moving parties to show the absence of factual issues and not on what constitutes a "genuine" factual issue. See, e.g., Celotex Corp. v. Catrett, 477 U.S. 317, 319 (1986) (resolving disagreement among circuits about whether moving party must show negation of factual element in question).

12. Summary judgment is appropriate when the "truth is clear" or when the moving party shows "that the opposing party cannot prevail under any circumstances." 10A C. WRIGHT, A. MILLER, \& M. KANE, supra note $7, \S 2725$, at $99-100$. 
clear if no rational jury presented with the evidence supporting an allegation could find the allegation to be true. ${ }^{13}$ The standard for legal claims under Rules 56 and 12(b)(6) is similarly careful; a claim will not be dismissed "unless it appears beyond doubt that the plaintiff can prove no set of facts in support of his claim which would entitle him to relief."14 The application of these standards preserves liberal access to the courts.

The standards for "grounded" facts and "warranted" law under Rule 11 are much less clear" and do not include consideration of whether a party could show facts entitling her to relief or whether a rational trier of fact could find an allegation to be true. Judges may use virtually any criteria to impose sanctions; as a result, Rule 11 has been applied inconsistently. ${ }^{16}$ The lack of clear Rule 11 standards confuses attorneys ${ }^{17}$ and may be unfair to litigants. ${ }^{18}$

13. See, e.g., Sartor v. Arkansas Natural Gas Corp., 321 U.S. 620, 624 (1944) (summary judgment "should be on evidence which a jury would not be at liberty to disbelieve"). The standard imposed is that of a directed verdict under FED. R. Crv. P. 50: if a reasonable jury could find against the moving party on the evidence offered, neither summary judgment nor a directed verdict is appropriate. Anderson v. Liberty Lobby, Inc., 477 U.S. 242, 250 (1986). See Currie, Thoughts on Directed Verdicts and Summary Judgments, 45 U. CHI. L. REV. 72, 79 (1977); Schwarzer, supra note 11, at 486.

14. Conley v. Gibson, 355 U.S. 41, 45-46 (1957).

15. Courts have been developing summary judgment standards since the enactment of the Federal Rules in 1938. In contrast, courts rarely applied Rule 11 before its amendment in 1983 but have extensively applied the Rule since that time. See, e.g., S. Burbank, Rule 11 in Transition: The Report of the Third Circuit Task Force on Federal Rule of Crvil Procedure 11 xiii (American Judicature Society 1989) (comprehensive empirical study of Rule 11 motions from 1987 to 1988 in Third Circuit, including unpublished decisions, found motions in .05\% of cases); S. KAssIN, An Empirical Study of Rule 11 Sanctions 6 (Federal Judicial Center 1985) (increase in frequency of Rule 11 application after amendments); T. Willging, The Rule 11 Sanctioning ProCESS 69 (Federal Judicial Center 1988) (very rough estimate of reported and unreported cases based on survey of judges indicates one sanctions award for every 280 filings; author believes estimate is probably inflated); Vairo, Rule 11 Revisited, 118 F.R.D. 189, 199 (1988) (688 Rule 11 decisions reported between August 1, 1983, and December 15, 1987). Consequently, the development of Rule 11 standards is in a much earlier stage than that of summary judgment standards. Furthermore, the Supreme Court has discussed summary judgment, but not Rule 11, extensively. E.g., Anderson v. Liberty Lobby, Inc., 477 U.S. 242 (1986) (discussing summary judgment standards in relation to directed verdict); Celotex Corp. v. Catrett, 477 U.S. 317 (1986) (discussing moving party's burden of proof in summary judgment); Adickes v. S. H. Kress \& Co., 398 U.S. 144 (1970) (discussing moving party's burden of proof).

16. See, e.g., S. KASSIN, supra note 15, at 6 (increase in uncertainty about Rule after amendments); Vairo, supra note 15, at 202 (1988) (Rule 11 not applied fairly or uniformly); Note, Plausible Pleadings: Developing Standards for Rule 11 Sanctions, 100 HARv. L. Rev. 630, 638 (1987) [hereinafter Note, Plausible Pleadings] (judges have produced "varied and inconsistent results"). But see Note, A Uniform Approach to Rule 11 Sanctions, 97 Yale L.J. 901, 909 (1988) (stating that uniform approach has evolved to identify when conduct is sanctionable under Rule 11).

17. See T. WItLGing, supra note 15, at 38 (Do attorneys have "a clear view of the standards by which their conduct will be measured under the amended rule? The early response to this question was a loud "No.' ").

18. The application of Rule 11 has raised due process concerns. See, e.g., Braley v. Campbell, 832 F.2d 1504, 1513 (10th Cir. 1987) (Rule 11 due process considerations include both specificity of findings and opportunity of sanctioned litigant to be heard); S. BURBANK, supra note 15, at 25-36 (discussing Rule 11 due process considerations); T. Willging, supra note 15, at 83 (due process clause clearly applies to sanctions decisions); see also Oliphant, Rule 11 Sanctions and Standards: Blunting the Judicial Sword, 12 WM. MrTchel. L. REv. 731, 743-44 (1986) ("Justice should not ... be sacrificed on the altar of expediency."). 
This Note attempts to clarify Rule 11 and argues that factual and legal issues that violate Rule 11 should be dismissed before they are sanctioned, using the standards of summary judgment or of Rule 12(b)(6). ${ }^{19}$ Once allegations are found to be dismissible under Rule 56 or 12(b)(6) (or some other procedure), ${ }^{20}$ a stricter standard should be applied to determine whether to impose sanctions. Sanctions, in addition to dismissal, should be imposed for unreasonable or dishonest presentation of meritless claims.

Section I describes the requirements of Rule 11, examines sources of confusion in application of the Rule, and argues that evaluation of factual and legal merits is an essential component of Rule 11. Section II reviews the standards used under summary judgment and Rule 12(b)(6) proceedings for evaluating factual and legal claims. Section III describes inconsistencies and problems with the application of Rule 11. Section IV argues for the use of summary judgment and Rule 12(b)(6) standards as minimal standards for the evaluation of factual and legal merits under Rule 11-to clarify the Rule and increase its fairness to litigants.

\section{The Gurrent State of Rule 11}

\section{A. Requirements of Rule 11}

Rule 11 contains two distinct clauses: the "grounded in fact and warranted by law" clause and the "improper purpose" clause. The first clause requires certification that a pleading, motion or other paper is "well grounded in fact and is warranted by existing law or a good faith argument for the extension, modification, or reversal of existing law . . . ."21 Certification under the first clause must be made "to the best of the signer's knowledge, information, and belief formed after reasonable inquiry." 22 The second clause requires that the document not be "interposed

19. Despite his conviction that the Rules do not raise similar issues, see supra note 8 , even Judge Schwarzer has questioned how "a case could be so frivolous as to warrant sanctions if lby virtue of denial of summary judgment] it has sufficient merit to get to trial." Schwarzer, Rule 11 Revisited, 101 Harv. L. Rev. 1013, 1019 (1988).

20. A claim may be more appropriately dismissed under some other procedure than under summary judgment or Rule 12(b)(6). For example, a frivolous motion should be denied before it is sanctioned. See, e.g., In re Disciplinary Action Against Mooney, 841 F.2d 1003 (9th Cir. 1988) (denying frivolous motion for removal from state court to federal court before sanctioning it).

21. FED. R. Civ. P. 11. This clause contains two prongs, factual basis and legal basis, both directed at the merits of the case. Schwarzer, Sanctions Under the New Federal Rule II-A Closer Look, 104 F.R.D. 181, 195 (1985).

22. FED. R. Crv. P. 11. There is no reason to investigate an attorney's inquiry if a document does not violate the "grounded in fact and warranted by law" clause. See Calloway v. Marvel Entertainment Group, 854 F.2d 1452, 1470 (2d Cir. 1988) (initial focus should be on evidentiary basis for factual claim; where such basis is shown, no need to investigate attorney's inquiry); Zaldivar v. City of Los Angeles, 780 F.2d 823, 831 (9th Cir. 1986) ("Of course, the conclusion drawn from the research undertaken must itself be defensible. Extended research alone will not save a claim that is without legal or factual merit from the penalty of sanctions."); Note, Plausible Pleadings, supra note 16 , at 642-43 ("reasonable inquiry" requirement serves to adjust standard of factual and legal ground to individual lawyer; in many cases courts infer reasonableness of inquiry from whether factual and legal issues have merit). Nevertheless, many commentators fail to analyze the "grounded in fact and 
for any improper purpose, such as to harass or to cause unnecessary delay or needless increase in the cost of litigation."23

The wording of the Rule, requiring certification of groundedness and improper purpose, implies that the two clauses are independent and violation of either clause is sufficient to trigger a violation of the Rule. ${ }^{24}$ The first clause is independent of the second clause because courts can evaluate the merits of factual and legal claims without considering an attorney's purpose. Evaluation of an attorney's inquiry does not require assessment of the attorney's purpose and it is often possible to determine if the "grounded in fact and warranted by law" clause has been violated by looking solely at the factual and legal merits of the papers presented to the court. ${ }^{25}$

The second clause, however, has seldom been applied independently of the first. Courts have rarely found a violation of the "improper purpose" clause without concurrently finding a violation of the "grounded in fact" clause, ${ }^{26}$ and courts in several circuits have decided that sanctions can never be imposed for a factually and legally valid case, even if it was brought solely for an improper purpose. ${ }^{27}$

warranted by law" requirements independently of the "reasonable inquiry" requirement. E.g., Bloomenstein, Developing Standards for the Imposition of Sanctions Under Rule 11 of the Federal Rules of Civil Procedure, 21 Akron L. Rev. 289, 296-302 (1988); Nelken, Sanctions Under Amended Federal Rule 11-Some "Chilling" Problems in the Struggle Between Compensation and Punishment, 74 GEo. L.J. 1313, 1340-42 (1986); Vairo, supra note 15, at 205-20; T. WILIGING, supra note 15 , at $35-53$.

23. FED. R. CIV. P. 11.

24. See Robinson v. National Cash Register Co., 808 F.2d 1119, 1130 (5th Cir. 1987) ("The two clauses state independent obligations, each of which must be satisfied."); Zaldivar v. City of Los Angeles, 780 F.2d 823, 832 (9th Cir. 1986) (conjunction "and" suggests that "the two clauses are to be viewed independently"). But see Note, Applying Rule 11 to Rid Courts of Frivolous Litigation Without Chilling the Bar's Creativity, 76 KY. L.J. 891, 903 (1988) (although "and" suggests independence between the clauses, some courts have not interpreted "improper purpose" clause as independent); see also infra note 27.

25. This is true when the factual and legal issues are so meritless that no reasonable attorney would have submitted them. See, e.g., Hill v. Norfolk \& W. Ry. Co., 814 F.2d 1192, 1201-02 (7th Cir. 1987) ("All the relevant 'conduct' is laid out in the briefs themselves; neither the mental state of the attorney nor any other factual issue is pertinent to the imposition of sanctions for such conduct.").

26. See, e.g, Golden Eagle Distrib. Corp. v. Burroughs Corp., 801 F.2d 1531, 1539 (9th Cir. 1986) (reversing district court sanctions against attorney for failure to cite adverse authority and for claim that argument was supported by existing law when it in fact required modification of law, stating that although the attorney's conduct was improper, it did not violate Rule 11), rev'g 103 F.R.D. 124 (N.D. Cal. 1984) (Schwarzer, J.). For one example where a court did sanction an attorney for presenting a legally sufficient document for improper purposes, see Cohen v. Virginia Elec. \& Power Co., 788 F.2d 247 (4th Cir. 1986). In Cohen the plaintiff's attorney submitted a legally sufficient motion which he planned to withdraw if it was opposed. In imposing sanctions the court stated that to save time and money he should have contacted the defendant's attorneys informally to find out if the motion would be opposed. Id. at 249. The result in Cohen is questionable because presumably the plaintiff's attorney could have decided not to withdraw the motion at any time, at which point the court would have had little justification for sanctions.

27. The court in Zaldivar v. City of Los Angeles, 780 F.2d 823, 832 (9th Cir. 1986) held that if a complaint was well-grounded, it could not violate the Rule on the basis of improper purpose (although it also noted that the wording of the Rule suggests independence between the clauses, see supra note 24). This holding has been followed in the Ninth Circuit, Hudson v. Moore Business Forms, Inc., 827 F.2d 450, 453 (9th Cir. 1987); Rachel v. Banana Republic, Inc., 831 F.2d 1503, 1508 (9th Cir. 1987), and echoed in the Tenth Circuit. Burkhart Through Meeks v. Kinsley Bank, 
Moreover, the "improper purpose" clause has been interpreted and applied inconsistently. Some courts and commentators have interpreted Rule 11 to authorize only an objective standard for findings of improper purpose. ${ }^{28}$ Others have suggested that the Rule merely no longer requires a subjective bad faith standard. ${ }^{29}$ Still others have interpreted the "improper purpose" clause as requiring subjective bad faith..$^{30}$

A litigant who brings a factually and legally valid claim solely for an improper purpose is morally wrong. Nonetheless, every legal action causes some harassment, delay, and cost and Rule 11 does not authorize courts to sift through factually and legally valid claims to weed out the least ethical. ${ }^{31}$ In most circumstances documents presented for an "improper pur-

852 F.2d 512, 515 (10th Cir. 1988) ("any suggestion of harassment would necessarily fail" if complaint was warranted by law). However, the Zaldivar court reserved the question of whether harassment by filing excessive motions, each one grounded in fact and law, could constitute a violation of the Rule. Zaldivar, 780 F.2d at 832 n.10. The Fifth Gircuit has followed the Zaldivar holding that filing a complaint that is factually and legally valid could not constitute harassment or improper purpose, although filing successive motions that are each factually and legally valid might constitute a Rule 11 violation. National Ass'n of Gov't Employees, Inc. v. National Fed'n of Fed. Employees, 844 F.2d 216, 224 (5th Cir. 1988); Robinson v. National Cash Register Co., 808 F.2d 1119, 1130 n.20 (5th Cir. 1987). Under these holdings the "improper purpose" clause is superfluous, at least for complaints. See also infra note 36 . It is unclear why these courts have made a distinction between complaints and motions; however, they would probably agree that Rule 11 authorizes sanctions for repetitive filings of complaints or motions that have been previously rejected. Many courts have held that such duplicative filings do constitute a Rule 11 violation even if the filing of the first one was not unreasonable enough to be sanctionable. See infra note 32 and accompanying text.

28. See, e.g., Zaldivar, 780 F.2d at 829 (no role for subjective standard in amended rule); Schwarzer, supra note 21, at 196 (Rule 11 cannot be effective if courts consider subjective bad faith). In Zaldivar, although the court noted that the wording of the Rule should indicate a subjective standard for determinations of intent, it followed what it regarded to be a "nearly unanimous" view that improper purpose must be tested by objective standards. $780 \mathrm{~F} .2 \mathrm{~d}$ at 831 n.9. The Zaldivar court cites Schwarzer, supra, and Eastway Constr. Corp. v. City of New York, 762 F.2d 243, 253 (2d Cir. 1985), cert. denied, $108 \mathrm{~S}$. Ct. 269 (1987) for this "nearly unanimous" view. However, the court in Eastway did not embrace this view but held only that a violation of the Rule no longer required a finding of bad faith. See infra note 29.

29. See, e.g., Oliveri v. Thompson, 803 F.2d 1265, 1275 (2d Cir. 1986) ("no necessary subjective component to a proper rule 11 analysis"), cert. denied sub nom. County of Suffolk v. Graseck, 480 U.S. 918 (1987); Eastway, 762 F.2d at 253 ("subjective good faith no longer provides the safe harbor it once did"); Westmoreland v. CBS, Inc., 770 F.2d 1168, 1177 (D.C. Cir. 1985) ("Rule 11 now incorporates... a abjective test").

30. See, e.g., McCauley, Rule 11 Sanctions: Contrasting Applications in the Second and Fourth Circuits, 46 MD. L. REv. 470, 479-80 (1987) (post-amendment application of improper purpose "may reflect the lingering influence of old Rule 11 and its subjective bad faith standard"); Nelken, supra note 22, at 1320 (amended Rule 11 "adds an objective layer to the subjective core of traditionally sanctionable bad faith conduct"); Grosberg, Illusion and Reality in Regulating Lawyer Performance: Rethinking Rule 11, 32 VILL. L. REv. 575, 592 (1987) (improper purpose implicitly requires finding of purposeful bad faith); Note, supra note 8 , at 1040 n.141 (questioning whether use of objective standard for improper purpose is logically coherent).

31. Browne, The Significance of the Signature: A Comment on the Obligations Imposed by Civil Rule 11, 30 Clev. ST. L. REv. 385, 401-02 (1981), states that a "client has a right to seek any lawful objective through legally permissible means and to present for adjudication any lawful claim, issue or defense. Further, every legal action causes harassment or injury to some extent." Browne cites the ABA Model. Code of Professional Responsibility EC 7-1, stating in part: "In our government of laws and not of men, each member of our society is entitled to have his conduct judged and regulated in accordance with the law; to seek any lawful objective through legally permissible means; and to present for adjudication any lawful claim, issue or defense." (Browne discusses OHio R. Giv. P. 11, which is essentially equivalent to FED. R. Crv. P. 11.) See also Golden Eagle Distrib. Corp. v. Burroughs Corp., 801 F.2d 1531, 1539 (9th Cir. 1986) (sanctions for improper conduct in bringing 
pose" must also present factual issues that are not "grounded" or legal issues that are not "warranted" to violate Rule $11 .^{\mathbf{3 2}}$

In some situations in which an attorney has submitted a fact to the court as true, a court may be presented with evidence that the attorney knew that the fact was untrue or otherwise knowingly misled the court. ${ }^{33}$ Dishonesty clearly violates both the "improper purpose" clause and the "grounded in fact" clause. ${ }^{34}$ Evidence that a claim is ungrounded, however, does not automatically lead to a conclusion of improper purpose; lack of ground in and of itself provides no evidence that an attorney acted either dishonestly or with intent to harass, delay, increase costs, or abuse the courts. ${ }^{35}$

In summary, documents that violate the "improper purpose" clause of

valid case overturned because court did not consider conduct to be type of ethical decision appropriate for Rule 11 sanctions, and because holding would require "district courts to judge the ethical propriety of lawyers' conduct with respect to every piece of paper filed in federal court").

32. One exception to this contention is the use of Rule 11 to sanction duplicative claims. A litigant whose original claim (which may not have deserved sanctions) is dismissed may not repeatedly press the same claim. See, e.g., Zaldivar v. City of Los Angeles, 780 F.2d 823, 832 (9th Cir. 1986) ("Without question, successive complaints based upon propositions of law previously rejected may constitute harassment under Rule 11."); Sanders v. City of Fort Wayne, 616 F. Supp. 467, 471 (N.D. Ind. 1985) ("Rule 11 is addressed to duplicative litigation of potentially meritorious claims just as surely as it is directed toward litigation of meritless claims"); Wm. Passalacqua Builders, Inc. v. Resnick Developers S., Inc., 611 F. Supp. 281, 285 (S.D.N.Y. 1985) (sanctions imposed for motion to dismiss where argument was identical to that presented in motion for reargument); Andre v. Merill Lynch Ready Assets Trust, 97 F.R.D. 699, 702 (S.D.N.Y. 1983) (advancement of claims previously held to be meritless is "harassing and coercive" under Rule 11).

33. An attorney's knowledge of the truthfulness of facts, of course, falls on a continuum ranging from very likely true to very likely untrue and the court's job is to assess whether an attorney was reasonably sure a fact was untrue.

34. Courts apply the improper purpose clause with good reason when evidence of attorney dishonesty exists. Evidence that an attorney had certain information and yet presented contradictory information shows dishonesty, and such information is clearly not "grounded." See, e.g., Calloway v. Marvel Entertainment Group, 854 F.2d 1452, 1472-74 (2d Cir. 1988) (plaintiff's attorney deliberately misrepresented expert opinion he had before him); National Ass'n of Radiation Survivors v. Walters, 111 F.R.D. 595, 603 (N.D. Cal. 1986) (defendant's attorney alleged that plaintiff's husband's death was due to alcoholism when death certificate stated death was due to cancer). Evidence may also exist of dishonest behavior that does not entail a direct falsehood. See, e.g., Chu v. Griffith, 771 F.2d 79, 81 (4th Cir. 1985) (plaintiff sanctioned for suing judge solely to convince judge to recuse himself from another case to which plaintiff was a party); see also Rubin v. Buckman, 727 F.2d 71, 72-73 (3rd Cir. 1984) (Attorneys who first alleged that plaintiff was citizen of Hong Kong, but after adverse summary judgment stated that he was U.S. citizen, "had either intentionally deceived the court" or "had been reckless." " 'One would have to be naive indeed' to believe that plaintiff's counsel learned of the existence of a jurisdictional defect only after the entry of an adverse judgment on the merits.").

35. Courts apply the improper purpose clause without good reason when they infer improper purpose from lack of merit without direct evidence of dishonest behavior. E.g., Hudson v. Moore Business Forms, Inc., 827 F.2d 450, 456 (9th Cir. 1987) (" "lack of justification" " for a counterclaim by defendants " 'raises a strong inference that the defendants' motive in bringing the counterclaim was to harass the plaintiff" (citing district court's earlier ruling in Hudson v. Moore Business Forms, Inc., 609 F. Supp. 467, 480 (N.D. Cal. 1985)); Taylor v. Belger Cartage Serv., Inc., 102 F.R.D. 172, 180 (W.D. Mo. 1984) (counsel "failed to ascertain the proper legal standard," "blindly and stubbornly opposed the motions for summary judgment," "relied primarily on his emotional belief," and therefore "wilfully abused the judicial process"), affd, 762 F.2d 665 (8th Cir. 1985). See Note, Plausible Pleadings, supra note 16, at 643-44 (sanctions imposed for improper purpose without direct evidence of bad faith threaten standards of liberal pleading, are unfair to lawyer, and insulate court from criticism because willful abuse of courts is less controversial than sanctions for incompetence). 
Rule 11 generally form a subset of those documents that violate the "grounded in fact" clause. Courts have a responsibility to decide factually and legally valid cases even when they impose harassment, delay, and costs. Consequently, virtually all Rule 11 decisions require consideration of the merits of factual and legal issues as well as consideration of unreasonableness or dishonesty. ${ }^{3 \mathrm{~B}}$

\section{B. The Enduring Confusion Surrounding Rule 11}

Rule 11 has confused courts and litigants since its inception; this confusion was not resolved by the Rule's amendment in 1983. Most of the confusion in the original version of the Rule stemmed from the bad faith requirement and its unclear relationship to lack of "good ground" and "sham or false" claims. ${ }^{37}$ Most of the confusion in the current Rule similarly stems from confusion between improper purpose and groundedness. ${ }^{38}$

The "good ground" and the "sham and false" provisions in and of themselves were sources of confusion to the original interpreters of the Rule. The term "ground" connotes support, foundation, or evidence, but "good ground" was interpreted to include both evidentiary and good faith evaluations. "Sham" connotes bad faith considerations and "false" sug-

36. See Note, Plausible Pleadings, supra note 16, at 642 n.65 (reasonable inquiry and improper purpose cannot be evaluated without consideration of merits of papers produced). It is hard to imagine what standard courts would apply if they gave no consideration to the factual and legal merits; it would be difficult to establish unreasonable inquiry into meritorious facts and law or to find dishonest presentation of facts without some knowledge of the actual truthfulness of those facts.

Burbank's Third Circuit study recommends that courts applying Rule 11 focus on "conduct" and not on "product," although it notes that "no court of appeals has unambiguously adopted a conduct approach" and that there is "no clear dichotomy between conduct and product approaches." S. BuRBANK, supra note 15, at 20. Burbank's view conforms to Judge Schwarzer's view. See infra note 82. Burbank's study, though, approves of inferring improper purpose or "conduct" from "product," $S$. BURBANK, supra note 15, at 20 , which presumably requires evaluation of "product."

Application of the "improper purpose" clause is highly problematic, for three reasons. First, the debate about the application of an objective standard to findings of improper purpose indicates that many courts equate improper purpose with subjective bad faith while other courts have rejected a bad faith standard for Rule 11. See supra text accompanying notes 28-30. Second, cases in the Fifth and Ninth Circuits holding that improper purpose cannot be found without concurrent violation of the "grounded in fact" clause indicate that the "improper purpose" clause is largely superfluous. See supra note 27. Finally, the tendency for courts to infer improper purpose from lack of merit may be unfair to litigants and may threaten existing pleading standards. See supra note 35.

37. FED. R. Civ. P. 11 prior to the 1983 amendments stated in part: "The signature of an attorney constitutes a certificate by him that he has read the pleading; that to the best of his knowledge, information, and belief there is good ground to support it; and that it is not interposed for delay." In addition, the Rule before 1983 provided that a pleading signed in violation of the rule "may be stricken as sham and false." For an excellent discussion of the confusion between honesty and falsity under the original Rule, see Risinger, supra note 9.

38. See, e.g., Grosberg, supra note 30, at 588-91 (discussing attempt by amenders to clarify Rule 11 and its continuing confusion). For additional discussion of the confusion between the two clauses, see Schwarzer, Rule 11 Revisited, supra note 19 and Note, supra note 8. See also supra note 36 (discussing confusion stemming from the "improper purpose" clause).

39. Risinger explains that the inclusion of the term "ground" in the original Rule 11 was "based on an historical misconception," Risinger, supra note 9, at 13, and that there was no clear historical definition of the phrase "good ground" prior to its inclusion in the Rule, id. at 9-14. Browne believed 
gests evidentiary considerations, but claims under the original Rule were never dismissed for being "sham" without a simultaneous finding that they were false..$^{0}$ Therefore, just as the "improper purpose" clause of the current Rule is not applied independently of the "grounded in fact" clause, the "sham" prong of the original Rule was never applied independently of the "false" prong, despite the implication of the phrase "sham or false." Accordingly, decisions applying the "sham or false" provision addressed the merits of the claim, and any inquiry into bad faith or attorney honesty was superfluous. ${ }^{41}$

The advisory committee, in amending Rule 11, recognized that the provision to strike as sham and false was ineffectual:

The provision in the original rule for striking pleadings and motions as sham and false has been deleted. The passage has rarely been utilized, and decisions thereunder have tended to confuse the issue of attorney honesty with the merits of the action. Motions under this provision generally present issues better dealt with under Rules 8 , 12 , or $56 .{ }^{.2}$

The committee-with this explanation-effectively contributed to the confusion. It did so by suggesting that decisions on the merits associated with the "sham and false" provision were more appropriately handled under summary judgment than under Rule 11 , while at the same time it amended the Rule to retain and strengthen Rule 11's most salient decisions on the merits-those associated with the "good ground" provision. ${ }^{43}$

that "good ground" under the original rule consisted of "the motivation behind the document, the legal theory underlying the document, and the factual basis for the document," and therefore incorporated both improper purpose and the factual and legal issues. Browne, supra note 31, at 399. Risinger did not regard the inquiry into ground as entirely an inquiry into falsity; this view is illustrated in his analysis of Freeman v. Kirby, 27 F.R.D. 395 (S.D.N.Y. 1961), where he notes that the judge struck the complaint for lack of good ground but explains that the judge must have found the pleading to be dishonest because he did not attempt to determine its truth. Risinger, supra note 9, at 40 . He also, though, characterizes the inquiry into groundedness as a question of evidentiary support. Id. at 52-54.

40. A motion to strike as sham and false existed prior to the enactment of the Federal Rules, but it was never used in the absence of a finding of falseness. Risinger, supra note 9, at 16 . Only one Rule 11 case prior to 1976 used this provision successfully, but that court based its dismissal on the lack of "gaod ground." Id. at 39-40.

41. Id. at 16 .

42. FED. R. Giv. P. 11 advisory committee note to 1983 amendments (citation to Risinger omitted). See also Risinger, supra note 9, at 34 (proposing that all Rule 11 determinations of factual truth or falsity be considered first through summary judgment).

43. The advisory committee removed the provision to strike as sham and false because it was used to evaluate the merits. Risinger proposed removing the provision from the Rule for another reason: because it resulted in dismissal. "[T]he sanction of 'striking' the pleading seems superfluous, since any pleading that would qualify for such 'striking' would be a proper subject for summary judgment . . . ." Risinger, supra note 9, at 16. See also Note, The Dynamics of Rule 11: Preventing Frivolous Litigation by Demanding Professional Responsibility, 61 N.Y.U.L. REv. 300, 330-31 (1986) (amendments removed authority to strike). Risinger concluded that "it is never proper to have a Rule 11 inquiry prior to a final determination of falsity, which in the normal case will occur either by trial or by summary judgment" (concurring in part with the conclusions of this Note). Risinger, supra note 9 , at 34 . 
If the advisory committee truly intended to remove decisions on the merits from Rule 11 and transfer them to summary judgment, the reform was misguided, because evaluation of the merits is integral to the Rule. ${ }^{44}$ A repeated attempt to remove consideration of the merits by repealing the "grounded in fact" and "warranted by law" provisions would be implausible-the Rule would be hollow in the absence of these provisions. This Note proposes an alternative solution: incorporation of the summary judgment standard into Rule 11.

\section{Standards for Factual and Legal Findings Under SUMMARY JUdGMENT AND RULE 12(b)(6)}

The purpose of summary judgment is to clear the courts of cases which present only legal issues and do not require a trier of fact-to "prevent vexation and delay," to expedite cases, and to avoid "unnecessary trials." The requirement for a "genuine issue of material fact" includes several considerations. If the parties agree on the facts, there is no dispute and no "issue." When a factual dispute will not affect the outcome of the case, it is not "material." Where it is clear that disputed material facts cannot be proven at trial, the issue is not "genuine." Courts evaluate the truthfulness of a factual allegation only when a question arises as to whether it is "genuine."

The summary judgment standard for determining whether an issue is "genuine" is the same as that used for a directed verdict or a judgment notwithstanding the verdict under Rule $50 .{ }^{46}$ If a reasonable jury could decide against the moving party, neither a directed verdict nor summary judgment is appropriate. ${ }^{17}$ To decide what conclusions a rational jury could draw, courts assess the sufficiency of the evidence; an allegation must be supported by substantial evidence. ${ }^{48}$ Assessment of the evidence requires consideration of the evidence available to both parties. ${ }^{49}$ Courts avoid decisions based on the credibility of witnesses ${ }^{50}$ and decide the truth-

44. See supra note 36 and accompanying text.

45. 10 C. WRIGHT, A. MILleR \& M. KANE, supra note 7, $\$ 2712$, at 564-67; see also Fontenot v. Upjohn Co., 780 F.2d 1190, 1196 (5th Cir. 1986) ("The function of intercepting factually insufficient claims is now assigned to the summary judgment.").

46. See 10A C. Wright, A. Miller, \& M. KANE, supra note 7, § 2725, at 103-104; Currie, supra note 13, at 79. FED. R. Civ. P. 50 provides procedures under which a judge presiding over a jury trial may direct the jury's verdict or enter judgment notwithstanding the verdict of the jury.

47. See Anderson v. Liberty Lobby, Inc., 477 U.S. 242, 250 (1986); RULES OF Grvil Procedure FOR THE UNITED STATES DisTRICT CouRTS, Rule 50 practice comment (written by T. Coyne); Schwarzer, supra note 11 , at 481.

48. See Schwarzer, supra note 11 , at $481 ; 10 \mathrm{~A}$ C. WRIGHT, A. MILlER, \& M. KANE, supra note $7, \S 2725$, at 103 .

49. In contrast, a court deciding whether an attorney who presented a dismissable fact was unreasonable under Rule 11 will evaluate only the evidence available to that attorney.

50. See Asbill \& Snell, supra note 11, at 1148-54. 
fulness of evidence only when it is so incredible that no rational jury could find otherwise. ${ }^{\text {s1 }}$

The purpose of Rule 12(b)(6) is also to clear the courts of cases that do not warrant trial. Rule $12(\mathrm{~b})(6)$, however, is "viewed with disfavor and is rarely granted." 22 A claim is not dismissed unless it is certain that a nonmoving party cannot show any set of facts entitling her to relief, ${ }^{53}$ and the "issue is not whether a plaintiff will ultimately prevail but whether the claimant is entitled to offer evidence to support the claims." 54

The summary judgment standard-consideration of the evidence available to assess whether a rational trier of fact could find for the party opposing summary judgment-allows dismissal of factual allegations only when they would be virtually impossible to prove at trial. ${ }^{55}$ The Rule 12(b)(6) standard-consideration of whether a non-moving party could prove any set of facts showing a claim for relief-allows dismissal only of invalid legal claims. Courts applying these standards are effective at clearing their dockets of cases that present solely legal issues or do not present a legal claim without threatening litigants' rights to a fair hearing.

\section{Standards and Applications of Rule 11}

In contrast to summary judgment, Rule 11 has not been developed to the extent that its standards go beyond the wording of the Rule to give cogent meaning to the "grounded in fact" and "warranted by law" requirements. Judges applying Rule 11 offer widely varying explanations for the imposition of sanctions. ${ }^{\text {se }}$ While in some circuits judges are now

51. See id., at 1170-71; Sonenshein, supra note 11, at 810; Note, supra note 9, at 517; see also 10 C. WRIGHT, A. MiLler, \& M. KANE, supra note 7, § 2712, at 582 (apparent existence of factual dispute does not automatically defeat Rule 56 motion). But see Note, Plausible Pleadings, supra note 16 , at 635 (summary judgment does not test veracity of evidence).

52. 5 C. Wright, A. Miller \& M. KANE, supra note 7, § 1357, at 598; see also 2A J. MOORE, J. LuCAS, \& G. GroetheER, JR., supra note 10 , at 110.07 .

53. Conley v. Gibson, 355 U.S. 41, 45-46 (1957); see also Hishon v. King \& Spalding, 467 U.S. 69,73 (1984) ("A court may dismiss a complaint only if it is clear that no relief could be granted under any set of facts that could be proved consistent with the allegations.").

54. Scheuer v. Rhodes, 416 U.S. 232, 236 (1974).

55. See generally Note, supra note 9, at 505 (explaining why judge's determination of point at which reasonable jury would draw particular inference is essentially same as judge's decision about that inference, but with much higher standard of proof).

56. See, e.g., Fontenot v. Upjohn Co., 780 F.2d 1190, 1196 (5th Cir. 1986) ("To permit the pleadings themselves to carry a case to trial when they rest only on the invention of counsel would permit ultimate circumvention of Federal Rule of Civil Pracedure 11."); Rodgers v. Lincoln Towing Serv., 596 F. Supp. 13, 17, 26 (N.D. Ill. 1984) (claims are "patently frivolous" or have "no basis whatever"; nothing more "than a 'bouillabaisse' of legal conclusions"), aff'd, $771 \mathrm{~F} .2 \mathrm{~d} 194$ (7th Cir. 1985). The empirical studies, including those of S. BuRBank, supra note 15, S. Kassin, supra note 15 , and T. Willuging, supra note 15 , have not included statistics on the reasons for imposition of sanctions for lack of factual ground or unwarranted legal claims. Burbank does provide information on the grounds for imposition of sanctions in the Third Circuit, but only divides the grounds into such categories as frivolous complaints, frivolous motions, inadequate inquiry, and harassment. S. BuRBANK, supra note 15, at 114. Also, the results of Burbank's Third Circuit study, the first empirical study to include unpublished decisions, indicate that studies that omit unpublished decisions are highly inaccurate. Id. at 59. 
required to arrive at specific findings for Rule 11 sanctions, ${ }^{57}$ judges in other circuits may decline to offer any explanation. ${ }^{58}$

Many judges have described the standard for Rule 11 in terms of "patently" ungrounded or "obviously" unwarranted claims with little or no explanation of what is patent or obvious. For example, in Doering $v$. Union County of Chosen Freeholders ${ }^{68}$ the court repeatedly states that Rule 11 is violated when claims are "clearly without merit" unmeritorious or frivolous" ${ }^{11}$ and Eastway Constr. Corp. v. City of New $Y_{\text {ork }} \mathbf{6}^{\mathbf{2}}$ is often cited for the statement that "where it is patently clear that a claim has absolutely no chance of success . . . Rule 11 has been violated." ${ }^{33}$ The courts in both of these cases dismissed the claim in question under separate summary judgment proceedings prior to the imposition of Rule 11 sanctions, but did not mention the summary judgment evaluations of evidentiary support in deciding whether to apply Rule 11. Standards for Rule 11 determinations require some criteria other than "obviousness."

Some courts consider more than "patent" lack of merit and evaluate the evidence supporting a factual allegation but do not apply the degree of cautiousness used in summary judgment. For example, in Frazier $v$. Cast ${ }^{64}$ police entered a suspect's burning house during a stakeout and

57. The Second and Tenth Circuits now require specific findings. Sanko S.S. Co. v. Galin, 835 F.2d 51, 53 (2d Cir. 1987) ("manner in which sanctions are imposed must comport with due process requirements" and court should set forth reasons why document is frivolous); Braley v. Campbell, 832 F.2d 1504, 1513 (10th Cir. 1987) (due process requires specific findings for sanctions because (1) there must be a "basis for imposition," (2) a sanctioned litigant has a due process right to notice and to an opportunity to be heard and must have sufficient explanation to be able to respond, and (3) decisions must be reviewable). The Seventh Circuit requests findings where a "substantial award" is involved. Brown v. Federation of State Medical Bds., 830 F.2d 1429, 1438 (7th Cir. 1987) ("we now" request that in cases involving substantial awards a district judge state with some specificity the reasons for the imposition of a sanction").

58. Some circuits have not discussed whether courts applying Rule 11 must arrive at specific findings. The Fifth and Sixth Circuits do not require judges to provide explicit findings. Thomas v. Capital Sec. Serv., 836 F.2d 866, 883 (5th Cir. 1988) (en banc) ("the rule we adopt does emphasize the importance of an adequate record for appellate review in those cases in which the violation is not apparent on the record ... [, but] the degree and extent to which a specific explanation must be contained in the record will vary accordingly with the particular circumstances of the case"); INVST Fin. Group v. Chem-Nuclear Sys., 815 F.2d 391, 401 n.4 (6th Cir.) (written findings of fact and law not required although such findings aid in appellate review), cert. denied, $108 \mathrm{~S}$. Ct. 291 (1987); see also Szabo Food Serv. v. Canteen Corp., 823 F.2d 1073, 1084 (7th Cir. 1987) ("When the motion for sanctions is foolish . . . the judge need not belabor the obvious."), cert. dismissed, $108 \mathrm{~S}$. Ct. 1101 (1988).

59. 857 F.2d 191 (3d Cir. 1988).

60. Id. at 192 (citing district court opinion).

61. Id. at 194 .

62. 762 F.2d 243 (2d Cir.1985), cert. denied, 108 S. Ct. 269 (1987).

63. Id. at 254. Eastway is cited for this statement, for example, in Oliveri v. Thompson, 803 F.2d 1265, 1275 (2d Cir. 1986), cert. denied sub nom. County of Suffolk v. Graseck, 480 U.S. 918 (1987); and Doering, 857 F.2d at 194. See also United Food \& Commercial Workers Union, Local No. 115 v. Armour and Co., 106 F.R.D. 345, 349 (N.D. Cal. 1985) (misrepresentation of facts so obvious that defendants should have requested telephone status conference with judge to have case dismissed rather than initiating summary judgment); SFM Corp. v. Sundstrand Corp., 102 F.R.D. 555, 557 (N.D. Ill. 1984) (Rule 11 applies to situations where "litigant's position is patently untenable").

64. 771 F.2d 259 (7th Cir. 1985). 
carried the suspect, who later died, outside. The suspect's wife sued for warrantless entry. The police raised the affirmative defense that the fire created exigent circumstances requiring them to enter to save the suspect's life. The court imposed sanctions against the police for the claim of exigent circumstances because it believed that the evidence clearly showed that the police had entered to apprehend the suspect rather than to save his life. ${ }^{65}$ In Muthig v. Brant Point Nantucket, Inc. ${ }^{66}$ a couple sued both an owner and a salesman of real estate for breach of contract and fraud; they also sued both defendants for intentional infliction of emotional distress because the owner was rude to them. The court found no evidence for the claim of intentional infliction of emotional distress against the salesman and no evidence of harm, an essential element of the claim for fraud. ${ }^{67}$

Neither the Frazier nor the Muthig court discussed whether a rational judge or jury could find the facts to be true based on the evidence. In contrast, summary judgment opinions are often explicit about this finding. ${ }^{68}$ The rational jury standard is critical to summary judgment because it offers more protection than a judge's own determination of whether an allegation is or is not true ${ }^{69}$ and assessment of evidence is a means for implementing the rational jury standard and not a replacement for that standard. Litigants subjected to the possibility of Rule 11 sanctions deserve at least as much protection as those subjected to the possibility of dismissal of their cases.

Courts applying summary judgment avoid dismissing allegations when the evidence supporting the allegation is based on witness credibility. However, in Chevron, U.S.A., Inc. v. Hand ${ }^{70}$ attorneys for three defendants entered into a stipulation for settlement of the case, but one of the defendants later claimed that she had not given her attorney authority to enter into the stipulation. The district court did not believe the defendant's testimony and imposed sanctions for her motion to set aside the stipulation. The appellate court did not reverse this finding despite noting that the matter turned solely on the issue of witness credibility. ${ }^{71}$

Judges applying Rule 11 to cases such as those described above may feel that the sanctioned claims are so obviously frivolous that no rational jury could possibly find them to be true and that there is no need to explain such manifest lack of ground. What strikes one judge as foolish,

65. Id. at 264 .

66. 838 F.2d 600 (1st Cir. 1988).

67. Id. at 605 .

68. See, e.g., Rachel v. Banana Republic, Inc., 831 F.2d 1503, 1507-08 (9th Cir. 1987) (court analyzed claim for summary judgment in terms of whether reasonable jury could disagree about facts but affirmed Rule 11 sanctions for different claim, merely upholding district court's finding that allegation "was completely lacking in factual basis").

69. See supra note 55 .

70. 763 F.2d 1184 (10th Cir. 1985).

71. Id. at 1186 . 
though, may strike another as reasonable, and there is bound to be disagreement among judges about what is obviously frivolous. ${ }^{72}$ Judges who feel strongly about cases they consider to be obviously meritless should both express their displeasure vehemently and explain their outrage using consistent standards. ${ }^{73}$

Many judges do not see a link between Rule 11 and summary judgment. For example, in Muthig v. Brant Point Nantucket, Inc. ${ }^{74}$ the plaintiffs claimed that because the district court had denied summary judgment, it could not impose Rule 11 sanctions. The court rejected this contention, stating "[n]or do we see the summary judgment standard (based on filed documents) and Rule 11's standard (based on what reasonable inquiry should have revealed, perhaps about other information) as necessarily or inevitably congruent." ${ }^{755}$ In affirming sanctions the court explained that at the time of summary judgment on the claim for intentional infliction of emotional distress, the district court had not yet been presented with the plaintiffs' depositions describing the salesman's behavior as polite. Presumably, summary judgment would have been successful if the depositions had been available to the court at the time, and the two procedures were independent in this case only because each involved evaluation of different evidence. The court confused the standard for Rule 11 in failing to recognize the relationship between Rule 11 and Rule 56; the relationship could have been clarified by an explanation noting that the plaintiff's argument would be correct in most circumstances but that the situation warranted an exception because new evidence arose after summary judgment.

In Kamen v. American Tel. \& Tel. Co. ${ }^{76}$ the plaintiff brought an action against her employer for failing to provide her with a smoke-free environment under a federal law requiring employers who have received "Federal financial assistance" to provide such an environment to employees, such as the plaintiff, who are highly sensitive to smoke. The appellate

72. Disagreement is evidenced by the number of Rule 11 decisions overturned on appeal. Willging's study showed that approximately one third of the appeals of Rule 11 decisions overturned the trial court's findings. T. WILLGING, supra note 15 , at 81 .

73. Judges are often very expressive in Rule 11 opinions. See, e.g., Eastway Const. Corp. v. City of New York, 762 F.2d 243, 245 (2d Cir. 1985) (plaintiff "sought vindication" and "somewhat desperately" brought this action); Browning Debenture Holders' Comm. v. DASA Corp., 560 F.2d 1078, 1083 (2d Cir. 1977) (allegations made "in an excessively detailed, prolix, and blunderbuss fashion"); Wrenn v. New York City Health and Hosp. Corp., 104 F.R.D. 553, 557 (S.D.N.Y. 1985) ("counsel has exhibited a cavalier, bordering on the contemptuous, disregard for the Federal Rules of Civil Procedure"); Rodgers v. Lincoln Towing Serv., Inc., 596 F.Supp. 13, 22 (N.D. Ill. 1984) (claim described as "ponderous, extravagant, and overblown"); Taylor v. Belger Cartage Serv., Inc., 102 F.R.D. 172, 181 (W.D. Mo. 1984) (sanctions warranted "[w] submit valid papers] due to laziness, greed, incompetence, or other distracting motives"). Expressions of outrage at litigators who abuse the courts are appropriately included in Rule 11 opinions; irresponsible litigators may be deterred by the unmistakable displeasure of judges.

74. 838 F.2d 600 (1st Cir. 1988).

75. Id. at 606 (emphasis in original).

76. 791 F.2d 1006 (2d Cir. 1986). 
court reversed the district court's imposition of sanctions, stating that "the action was dismissed for failure to make [a reasonable] inquiry [into whether the employer received Federal financial assistance] . . . Sanctions were then imposed because the district court rejected the merits of plaintiff's argument."77 The court explained that "just as summary judgment or a 12(b) motion cannot be boot-strapped onto a finding of a Rule 11 violation, an improper grant of dismissal cannot be the basis for Rule 11 sanctions."78 The court could have clarified the relationship between Rules 11 and $12(b)(6)$ by explaining that the district court should have first dismissed the claim under Rule 12(b)(6) on the basis of lack of merit without using a "reasonable inquiry" criteria, and then considered whether sanctions were appropriate on the basis of a "reasonable" standard. Instead, the court regarded the Rules as entirely independent, noting only that "neither Rule 56 nor Rule 12(b) was in any way modified by the adoption of the 1983 amendments to Rule $11,{ }^{\prime \prime 79}$ which is true, but not enlightening.

The court in Steinberg v. St. Regis/Sheraton Hotel ${ }^{80}$ presented the relationship between Rule 11 and Rule 56 in an even more puzzling form. In Steinberg a plaintiff's claim survived summary judgment but was later found to be in violation of Rule 11. The court recognized the "unfortunate irony" of the situation but also proposed that because the plaintiffs were given "the benefit of the doubt" at summary judgment, the court was "now confronted with the defendant's very compelling application for attorney's fees." uated at summary judgment was any different than that evaluated in the Rule 11 proceedings, and there is therefore no apparent reason why the plaintiff's claim should have been sanctioned for a Rule 11 violation when it was sufficiently valid to have survived a summary judgment challenge. The court in this case confused the standard for Rule 11 by implying that survival of a summary judgment motion and trial of the questionable issues might actually contribute to the risk of sanctions after trial.

These examples are representative of the ways in which courts have failed to develop a clear standard for Rule 11 violations and have defined the relationship between Rule 11 and Rule 56 inconsistently.

\section{SOlution}

Evaluation of the merits of factual and legal issues is not only appropriate under Rule 11-it is a primary concern and an integral part of the investigation into an attorney's inquiry or purpose. Courts evaluating mo-

77. Id. at 1012 (emphasis in original).

78. Id. at 1014 .

79. Id. at 1011.

80. 583 F. Supp. 421 (S.D.N.Y. 1984).

81. Id. at 424 . 
tions for summary judgment and Rule $12(\mathrm{~b})(6)$ employ widely accepted criteria for evaluating factual and legal claims, and application of the summary judgment and 12(b)(6) standards effectively denies dismissal of arguments that could prevail at trial. The standard for evaluating sanctionable facts and law under Rule 11 should be even more lenient than the summary judgment and Rule 12(b)(6) standards.

The following framework clarifies the relationship between the requirements for alleged facts under Rules 11 and 56. If the factual basis of an allegation meets the standard for a triable issue under Rule 56 and summary judgment is denied, then Rule 11 sanctions are inappropriate. If the factual basis does not meet the Rule 56 standard and the allegation is dismissed under summary judgment, Rule 11 sanctions may or may not be appropriate based on a standard of what is reasonable. Conversely, if the factual basis fails to meet the Rule 11 standard for "grounded" facts and deserves sanctions, then it must also be insufficiently "genuine" to avoid Rule 56, and dismissal must be appropriate. But if the factual basis is "grounded" for purposes of Rule 11, dismissal under summary judgment may or may not be appropriate.

Likewise, if the legal basis for a claim meets the standard for Rule $12(b)(6)$ and a motion to dismiss for failure to state a claim is denied (under either Rule 12(b)(6) or Rule 56), then Rule 11 sanctions for submitting a claim that is not "warranted by law" must be inappropriate. If Rule $12(b)(6)$ or 56 is applied to dismiss a motion for failure to state a claim, Rule 11 sanctions may or may not be appropriate. Conversely, if a legal claim is "unwarranted" and sanctionable under Rule 11 it must fail to state a claim under Rule 12(b)(6), but if it is "warranted" for purposes of Rule 11, dismissal for failure to state a claim may or may not be appropriate.

The relationship between Rule 11 and Rules 56 and 12(b)(6) implies that a Rule 56 or $12(\mathrm{~b})(6)$ motion should usually precede or coincide with a Rule 11 motion. ${ }^{82}$ It also suggests that courts should rarely decide

82. This is how Rule 11 is already applied in a large number of cases. Nelken's figures indicate that Rule 11 sanctions were sought together with dismissal under either Rule 12(b)(6) or Rule 56 in one third of the 233 cases published between August 1, 1983, and August 1, 1985. Nelken, supra note 22 , at 1327. Willging's figures are even higher, indicating that two-thirds of sanctions decisions were sought in conjunction with motions to dismiss or during or after summary judgment. $T$. WILLGING, supra note 15 , at 77 . Risinger concludes that Rule 11 should be applied in conjunction with summary judgment. Risinger, supra note 9, at 34. Nelken explains that it "is not surprising" that a high percentage of Rule 11 motions are sought in conjunction with Rule 12(b)(6) or Rule 56 motions, "since these are the two primary pretrial vehicles for examining the factual and legal merit of a claim." Nelken, supra note 22, at 1327. For an example of this type of application, see Eastway Constr. Corp. v. City of New York, 762 F.2d 243 (2d Cir. 1985), cert. denied, 108 S. Ct. 269 (1987), where the court carefully considered the merits of each claim for the summary judgment decision and then imposed sanctions because no competent attorney would have believed that the claim had a chance of success.

Judge Schwarzer contends that courts are applying Rule 11 as an "enhancement" to summary judgment:

The purpose of the rule, as stated by the Advisory Committee, is twofold: "[to] discourage 
whether facts are "grounded" under Rule 11 on the basis of a pleading alone before the introduction of evidentiary material in other admissions on file such as affidavits, depositions, and answers to interrogatories. ${ }^{83}$ Any claim, defense, motion, or part thereof which is sanctioned should also be dismissed. ${ }^{84}$ This procedural "ordering" of the Rules would help to clarify the confusion inherent in Rule 11 and to insure that litigants' factual and legal claims are given adequate consideration. It also eliminates the inconsistency created by the current use of different standards for pre-trial factual and legal findings.

Clearly, litigants should not be sanctioned merely for presenting an issue that is dismissible under summary judgment. ${ }^{85}$ Rule 11 sanctions are warranted only when the court has evidence of dishonesty or an issue is so meritless that no reasonable attorney would have presented it to the court. ${ }^{86}$ Proof of dishonesty should always result in the imposition of sanc-

dilatory or abusive tactics and help to streamline the litigation process by lessening frivolous claims or defenses." Without explicitly articulating an interpretative rationale, courts often tend to emphasize the second purpose, focusing on the merit-or lack of merit-of claims and defenses. This has made rule 11 analogous to an enhancement statute under which a penalty is added when a dismissal is sufficiently emphatic; courts distinguish between claims and defenses that are meritless and those that are so meritless as to warrant sanctions.

Schwarzer, Rule 11 Revisited, supra note 19, at 1018-19 (citation omitted). Schwarzer, however, laments the fact that some courts tacitly do what this Note proposes they should be doing explicitly in every case-evaluating the merits of the factual issues. Schwarzer proposes that courts shift their focus from the merits to the reasonableness of the inquiry and the improper purpose provision of the Rule, id. at 1020, and concludes that if courts concentrate on process and reasonable inquiry and avoid the question of whether a claim or defense is frivolous, Rule 11 decisions will be more consistent. Id. at 1024-25. He does not explain how an attorney's inquiry into the facts and law can be assessed without evaluation of the facts and law underlying the inquiry. See supra note 36 (discussing why investigation of merits is crucial). Judge Schwarzer's proposal would be attractive if it were realistically attainable. Unfortunately, it is impossible to identify attorneys who act improperly without also evaluating the cases they bring.

83. Cf. Marcus, The Revival of Fact Pleading Under the Federal Rules of Civil Procedure, 86 Col.um. L. REv. 433 (1986) (factual allegations should not be evaluated at pleading stage, liberal pleading requirements under Rule 8 should be maintained, and summary judgment should be strengthened); Note, Plausible Pleadings, supra note 16, at 637 (Rule 11, when imposed at the pleading stage, conflicts with liberal pleading scheme favored by Federal Rules of Civil Procedure).

84. Claims dismissed under other procedures also should not be sanctioned prior to dismissal. Any claim or allegation sufficiently meritless or improper to be sanctioned should not be heard by the courts. If evidence of a Rule 11 violation emerges after trial, one would hope that the sanctionable claim did not prevail at trial.

85. See Gaiardo v. Ethyl Corp., 835 F.2d 479, 483 (3d Cir. 1987) ("Litigants misuse the Rule when sanctions are sought against a party or counsel whose only sin was being on the unsuccessful side of a ruling or judgment. Restated, Rule 11 sanctions awarding counsel fees do not automatically or usually follow an adverse judgment or ruling. Substantially more is required."); Zaldivar v. City of Los Angeles, 780 F.2d 823, 830 (9th Cir. 1986) ("the granting of a motion to dismiss the complaint for failure to state a claim, or the granting of a summary judgment against the pleader is not dispositive of the issue of sanctions"). See generally Bloomenstein, supra note 22, at 296-97 (unsuccessful actions are not necessarily unreasonable). Under the American system of litigation, unsuccessful parties pay their own costs. If dismissed cases were automatically sanctionable, our system would approximate the English system of holding unsuccessful parties responsible for the costs of successful parties. The American system, however, operates in conjunction with the liberal pleading standards of FED. R. CIV. P. 8 and other federal rules to insure open access to the courts.

86. See Note, Plausible Pleadings, supra note 16, at 650 (Rule 11 should be applied under "grounded in fact" and "warranted by law" clauses only when claim would fail to survive motion to dismiss and no reasonable attorney could have thought there was a valid argument for modification of 
tions, and courts have good reason for imposing greater sanctions on dishonest attorneys or parties than on unreasonable attorneys or parties when they have clear evidence of dishonesty.

To determine whether a meritless case is unreasonable, courts should examine the circumstances in which the attorney operated, the resources available to clients and attorneys, the attorney's experience, and other differences among cases. ${ }^{87}$ The difficulties of determining what constitutes unreasonable behavior are far from trivial, but standards based on reasonableness are familiar to courts and litigants. Courts applying Rule 11 are developing standards for how unreasonable a meritless and "dismissible" claim must be to constitute a Rule 11 violation. ${ }^{88}$

Courts should also distinguish between areas of law to determine what is reasonable. Rule 11 should be applied more frequently to wellestablished or inherently simple areas of law and more sparingly to unsettled or complex areas of law. For example, one current and very serious problem with Rule 11 is that it is applied with much greater frequency to civil rights plaintiffs and their attorneys than to other types of litigants. ${ }^{88}$ Many civil rights claims are legally innovative. ${ }^{30}$ They are also factually difficuly to prove, particularly when they involve allegations of intent to discriminate. Civil rights claims therefore are subjected more frequently to Rule 11's requirements for factual and legal merits. ${ }^{91}$ Although it is tempting to conclude, as does Burbank, that the solution to this problem is to abstain from making factual and legal evaluations and concentrate on

existing law).

87. Investigation of the attorney's inquiry should take place after dismissal. The Advisory Committee has made it clear that the standard for the inquiry is one of reasonableness under the circumstances, including the time available to the attorney and the extent to which it was necessary to rely on the plaintiff for facts or to rely on other attorneys. FED. R. Crv. P. 11 advisory committee's note to 1983 amendments. Courts have considered such factors as whether discovery was required to find evidence for a fact, see, e.g., Touchstone v. GBQ Corp., 596 F. Supp. 805, 810 (E.D. La. 1984), the attorney's experience, and the resources available to the attorneys, such as the client's ability to pay for discovery. See Nelken, supra note 22, at 1319-20.

88. See, e.g., Gaiardo v. Ethyl Corp., 835 F.2d at 485 (although handbooks describing company policy do not constitute employment contracts under applicable Pennsylvania law, the issue is controversial; dismissal was therefore warranted but sanctions were not because sanctions would "chill effective advocacy"); Rachel v. Banana Republic, Inc., 831 F.2d 1503, 1508 (9th Cir. 1987) ("although counsel failed to adduce sufficient support for the allegations, the action was not so 'baseless' or 'lacking in plausibility' as to warrant sanctions"); Kamen v. American Tel. \& Tel. Co., 791 F.2d $1006,1012-13$ (2d Cir. 1986) (sanctions reversed because it was "far from clear" what federal funding fell under statutory definition of "Federal Financial assistance" and although case was dismissed, claim was not unreasonable).

89. Burbank's data shows that sanctions were imposed on civil rights plaintiffs, their attorneys, or bath in $47 \%$ of the Rule 11 cases and imposed on non-civil rights plaintiffs in only $8.5 \%$ of Rule 11 cases. S. Burbank, supra note 15, at 68-69.

90. For example, claims alleging discriminatory impact under Title VII of the Civil Rights Act of 1964 demonstrate an area of unsettled civil rights law. The Supreme Court has recently narrowed these claims significantly. Wards Cove Packing Comp. v. Atonio, 109 S. Ct. 2115 (1989).

91. Another possible explanation for the high rate of sanctions in civil rights cases is that some judges may simply be hostile to these claims; such judges may believe that most civil rights cases are meritless and should be deterred. 
the intent of civil rights attorneys and plaintiffs, ${ }^{92}$ that conclusion obfuscates the problem because of the difficulties of applying the improper purpose clause and of separating the analysis of purpose from that of merit. ${ }^{23}$ Judges should apply a less strict standard for both dismissal and sanctions in civil rights cases because these cases generally involve more recent legal developments. Civil rights cases, like antitrust cases, ${ }^{94}$ should also be given more lenient treatment because they are inherently difficult to prove. ${ }^{95}$ In contrast, judges should award sanctions more frequently in wellestablished areas of law, such as tax protester cases. ${ }^{96}$

Under the procedural "ordering" suggested above, judges should dismiss claims under Rule 56, Rule 12(b)(6), or some other established procedure before imposing sanctions under Rule 11. The current wording of the Rule does not preclude this method of applying Rule $11,{ }^{97}$ however, in order to secure and standardize its protections to litigants, Rule 11 should be amended to explicitly authorize the dismissal of frivolous claims and the use of summary judgment standards. The Rule could be applied effectively with two requirements: 1) that attorneys and parties submit only factual and legal issues that are honestly presented and reasonable based on the circumstances of the case and the pre-trial inquiry; and 2) that all issues of fact and law that are to be sanctioned before trial first be dismissed under Rule 56, Rule 12(b)(6), or other established procedures. ${ }^{98}$

\section{ConClusion}

Rule 11 was rarely applied before 1983 . Since 1983 , courts have been criticized for rampantly applying the Rule. ${ }^{98}$ The rate of application in-

92. See also $\mathrm{S}$. Burbank, supra note 15 at 72 (concluding that certain civil rights cases provide strong reasons to prefer a "conduct" rather than a "product" approach to the application of Rule 11).

93. See supra note 36.

94. See, e.g., Poller v. CBS, Inc., 368 U.S. 464, 473 (1962) ("summary procedures should be used sparingly in complex antitrust litigation where motive and intent play leading roles, the proof is largely in the hands of the alleged conspirators, and hostile witnesses thicken the plot").

95. But see Oliveri v. Thompson, 803 F.2d 1265, 1280 (2d Cir. 1986) (attorneys who handle unpopular civil rights cases are not held to different standard under Rule 11), cert. denied sub nom. County of Suffolk v. Graseck, 480 U.S. 918 (1987).

96. For example, claims challenging mandatory tax payments, such as the argument that wages are not income or that the Sixteenth Amendment was never ratified, have been repeatedly rejected by courts. See, e.g., Miller v. United States, 868 F.2d 236, 241-42 (7th Cir. 1989) (validity of Sixteenth Amendment is settled law and court "will deal harshly with frivolous tax appeals and will not hesitate to impose sanctions"); Connor v. Commissioner of Internal Revenue, 770 F.2d 17, 20 (2d Cir. 1985) (argument that wages are not income "has been rejected so frequently that the very raising of it justifies the imposition of sanctions"). On the other hand, many tax resisters bring actions pro se and should not be held to the same standard for knowledge of the law as attorneys.

97. However, Rule 11 does not provide for dismissal, and a party may move for Rule 11 sanctions but not for dismissal. In this case, courts could issue summary judgment sua sponte, but this is not common practice. Courts could also impose the "sanction" of dismissal because Rule 11 does not limit sanctions to monetary sanctions. There alternatives, however, provide means of skirting the problem rather than clarifying the Rule for litigants.

98. The "improper purpose" clause could be replaced by a requirement for honest and reasonable presentation without sacrifice to the integrity of the Rule.

99. See, e.g., Nelken, supra note 22, at 1352 (amended Rule 11 has "chill[ed] vigorous advo- 
creased after the Rule's amendment largely because courts interpreted the "reasonable inquiry" provision as authorization of an objective standard rather than the old, subjective, bad faith standard. Nonetheless, the 1983 amendments did little to illuminate the sources of confusion in the Rule. Courts before and after 1983 have not applied clear standards for findings of lack of "ground" and have been reluctant to find bad faith or improper purpose in the absence of meritlessness; courts applying the amended Rule have also inferred improper purpose without sufficient evidence. Explicit consideration of factual and legal issues under the established standards of summary judgment would reduce unwarranted Rule 11 motions by helping attorneys to identify sanctionable cases. Use of established standards would also improve fairness to litigants. 